\title{
Spatial and temporal variation of diversity seaweed (rhodophyceae, chlorophyceae and Phaeophyceae) in the Marchica lagoon (North-East Morocco)
}

Asmae AKNAF ( $\sim$ asmae_facul@hotmail.fr)

Universite Mohammed Premier Oujda Faculte Pluridisciplinaire de Nador https://orcid.org/0000-00015450-4018

\section{Mustapha AKODAD}

Universite Mohammed Premier Oujda Faculte Pluridisciplinaire de Nador

Mostafa Layachi

INRH: Institut National de Recherche Halieutique

Mourad Baghour

Universite Mohammed Premier Oujda Faculte Pluridisciplinaire de Nador

\section{Brahim OUDRA}

Cadi Ayyad University: Universite Cadi Ayyad

\section{Research Article}

Keywords: Marchica lagoon, Algae, Ecological, New pass, Rhodophyceae, Phaeophyceae

Posted Date: February 28th, 2022

DOI: https://doi.org/10.21203/rs.3.rs-1375988/v1

License: (c) (1) This work is licensed under a Creative Commons Attribution 4.0 International License.

Read Full License 


\section{Abstract}

The present work is mainly devoted to determine the distribution spatio-temporel seaweeds inventory of the Marchica lagoon. Several sampling campaigns, carried out at the Marchica lagoon (October 2014, January, April, July 2015, and July 2017), had the following objectives: To study the diversity Seaweeds (macroalgal) in different zones of the Marchica lagoon (north-eastern of Morocco), and stadies the spatio-temporal variation of the Marchica algae. The results obtained provided the identification of about 59 algae species inventories, with the dominance of rhodophyceae Ceramieae C. Agardh is a highly diverse group in terms of number of taxa followed by chlorophyceae and fucophyceae. Chlorophyceae make up the majority of the stand during the spring period, but during the summer period the stand experiences a decrease in chlorophyceae and an increase in rhodophyceae. Rhodophyceae (Gracilaria) are the most abundant seaweeds species at the continental edge, near Oued Tirkâa, at the southeast and south of the lagoon. However, chlorophyceae and rhodophyceae (Gracilaria) are located in large quantities near the new pass. While for the fucophyceae, we noticed the new species of $C$. barbata, which is not found by González and Conde (1991).

\section{Introduction}

Algae are of paramount ecological importance in the water body as it represents the food source for the higher trophic levels, and they are the most productive photosynthetic organisms in the world (Kasting et al. 2002). However, sometimes this food, stimulated by nutrient inputs (agricultural or domestic discharges also rich in chemical, organic or mineral contaminants), constitutes a major problem (ecological and sanitary) both for the population, which uses the water resources, and for the fauna and flora for which water represents the living environment (Viessman et al. 2009). For this reason, regular monitoring, aimed at surveillance and control of the development of this seaweed, is necessary.

Algae are chlorophyllous organisms capable of occupying all types of environments, although they are abundant in fresh and marine waters, on damp ground and even on snow. They also exist in all humid environments and tropical regions, and can be found even on the walls of buildings. They can be endophytes of certain protozoa or metazoa. Some algae associate with fungi and form lichens. They are divided into 6 large phylums according to the nature of the pigments and cell reserves; these are Cyanophytes, Chlorophytes, Euglenophytes, Chrysophytes, Rhodophytes and Pyrrhophytes (Iltis 1980). In this work we are interested in Seaweed. It is limited to tidal, photic and benthic areas and contributes to $10 \%$ of total marine productivity (Seckbach 2010). Algae are the main habitat generators. Changes in global temperature and ocean chemistry have been associated with increased concentrations of greenhouse gases, which have had an effect on biological systems, causing large-scale changes. In addition, these algal ecosystems contribute to the development of global socio-economic activities through their use in food, agriculture and industry. Algae are a bioindicators of ecosystem health and integrity because they form the basis of most food chains in aquatic environments, and of the properties of their components. They are used in many sectors: Agriculture and horticulture, the exploitation of algae in agriculture is also a way of adding value to algae. At present, we are moving towards the use of 
extracts that not only act as fertilizers, but also accelerate growth and protect crops, limiting the antifungal activity (Nafis et al. 2021). Farmers use algae to strengthen plants natural defences, instead of using, for example, pesticides. These new products, commonly known as SDN (Natural Defense Stimulator), could eventually replace certain phytosanitary treatments (Jaulneauet al. 2010). In the medicinal and pharmaceutical field, through their anti-amyloidogenic role (Vasarri et al. 2020), antibacterial, antiviral, antimyco-bacterial, antiplasmodial, antiprotozoal, antifungal and strongly antiinflammatory properties (Allmendinger et al. 2010; Oumaskour et al. 2013; Spavieri et al. 2013; khelil-Radji et al. 2017; Nafis al. 2021), having antitumor and antioxidant potential on human colorectal adenocarcinoma cells (Zbakh et al. 2014). Indeed, green algae contain a family of sulphated polysaccharides called ulvanes, which are the subject of several studies aimed at highlighting their beneficial activities in protecting plants against pathogens (Misurcova et al. 2012). Seaweeds are also used in the pharmaceutical industry (Trono, 1973; Febles et al. 1995; Lima-Filho et al. 2002; Ely et al. 2004; Inci et al. 2006). In cosmetics, Algae are an excellent source of minerals with a high affinity for skin cells. Seaweeds as source of dyes, of aromas and of fragrances (Couteau and Coiffard 2016). Algae extracts are used as active ingredients for hydrating and anti-ageing products (Couteau and Coiffard, 2016), thanks to the wealth in complete supply of active elements nourishes, stimulates epidermal cells and promotes skin renewal. For example, minerals contribute to the good balance and vitality of the cells, notably by participating in the activity of numerous enzymes (Nahas et al. 200; Cardozo et al. 2008; Li et al. 2009). Renewable energy, its special interest was devoted to micro- and macro-algae for biofuel production (Chisti 2007; Hankamer et al. 2007). At present, an industry is developing to produce biofuels from lignocellulose, so-called second and especially third generation biofuels (Didderen et al. 2008). According to El Asri et al (2017a and b), the Caulerpa prolifera, Gracilaria bursa-pastoris, Colpomenia sinuosa and Alsidium corallinium species in the Marchica lagoon present an exploitable energy reserve. The alginates salts extracted from algae are of great interest in the textile industry, they play an essential role in fixing colours in a fabric (Pereira and Cotas 2020). This alginate allows better penetration of the colour into the textile fibres but does not prevent the sun's rays from progressively reducing contrasts. Whereas in environment, algae play an important role for biodiversity, nutriment cyclique and ecosystems services in nearly all environment (Preirna and Neto 2014) and in maintaining the balance of aquatic environments, as primary producers and an important source of oxygen for the links in the ecosystem's food chain. As pollution indicator organisms, some red algae (Alsidium sp., Sargassum fluitans) (Figueira et al. 1997; Matoir et al. 2015), green algae (Ulva rigida, Chaetomorpha linum, Caulerpa prolifera, Enteromorpha intestinalis, Chaetomorpha linium, Ulva lactuca) (Kaimoussi et al. 2004; Chouba et al. 2010; Rahmouni et al. 2016) and brown algae (Ascophyllum nodosum, Fucus vesiculosus (Kuyucak et Volesky 1988; Holan et Volesky 1994; Fourest et Volesky 1997) are used to examine and assess the state of contamination by certain heavy metals. Because of their ability to bio-accumulate pollutants, these algae often considered as bioindicators of pollution and could be used in phytoremediation, mainly the species of Chaetomorpha aerea (Aknaf et al. 2018) for chlorophyceaes, while for rhodophyceaes : Alsidium corrallinium and Gracilaria gracilis which have a higher level of protection against climate changes (Aknaf et al. 2020). This work was carried out in parallel with other parameters, namely sedimentological, biological and chemical (Aknaf et al. 2015, 2018 (a, b), 2017(a, b), 2021). 
The purpose of this research was to evaluate the spatial and temporel distributions of the algae inventory of the Marchica lagoon, as well as their in relation to environmental variations and the dominant species distribution of Seaweeds in lagoon after opening the new pass in 2011.

\section{Materials And Methods}

Marchica lagoon $\left(35^{\circ} 05^{\prime}\right.$ and $35^{\circ} 14^{\prime} ; 2^{\circ} 44^{\prime}$ and $\left.2^{\circ} 56^{\prime} \mathrm{W}\right)$ is located on the northeast coast of Morocco. It's the largest Moroccan lagoon and the second largest in North-Africa and represents a parallel system (Ruiz et al. 2006; Zerrouqui et al. 2013). Marchica lagoon is part of the Moroccan Mediterranean wetland complex with an area of $115 \mathrm{~km}^{2}$, its maximum depth is about 7.5 meters in the middle and decreases towards the shore. It is separated from the sea by a $25 \mathrm{~km}$ long dune barrier that runs parallel to the coast in a north I west/south-east direction. In 2011, the lagoon is connected with Mediterranean Sea by the new pass opening of $300 \mathrm{~m}$ wide and $6 \mathrm{~m}$ deep, which water exchanges takes place, and is manifested by a decrease in eutrophication (Aknaf et al. 2015).

The samples were collected in October 2014, January, May, July 2015 and July 2017 along the Marchica lagoon at eleven sampling stations established to cover the different areas of the Marchica lagoon (Fig. 1). In the laboratory, the sample was stored in $5 \%$ formulated seawater for the floristic study. Anatomical section was mode by hand with à razol blande. The identification of the species, we used a binocular magnifying glass and the optical microscope. Based on systematic works and specialised literature, notably those of Cabioc'h et al. 2006; Lauret et al. 2011 and AlgaeBase (Guiry and Guiry 2015).

\section{Results}

The inventory of Seaweeds and epiphytes collected in the Marchica lagoon during the period October 2014 to July 2015 and July 2017 is presented in the table below (Table 1). It also indicates the geographical distribution of each species in the lagoon. The total number of taxa identified includes 59 species, of which 26 species of chlorophyceae, 29 species of rhodophyceae and 4 fucophyceae, in addition to two species of flowering plants: Cymodocea nodosa and Zostera noltei. 
Table 1

Taxons of Seaweeds identified in the Marchica lagoon during the study period

\section{Stations}

\section{Species}

\section{Cholophyceae}

\section{Ulvales}

Blidingia marginata (J. Agardh)

Enteromorpha compressa(Linnaeus)

Enteromorpha flexuosa (Wulfen) J

Enteromorpha intestinalis (Linnaeus)

Enteromorpha linza (Linnaeus)

Enteromorpha multiramosa Bliding.

Enteromorpha prolifera (O. F. Müller) J. Agardh

Enteromorpha torta (Mertens) Reinbold

Ulva intestinalis (Linnaeus), 1753

Ulva fasciata (Delili)

Ulva rigida C. Agardh1823

\section{Cladophorales- Cladophoraceae}

Chaetomorpha aerea (Dillwyn) Kützing, 1849

Chaetomorpha linum (O. F. Müller) Kützing

Cladophora coelothrix Kützing

Cladophora dalmatica Kützing

Cladophora vagabunda (Linnaeus) Van den hoek, 1963

Cladophora echinus (Biasoletto) Kützing

Cladophora prolifera (Roth) Kützing

Cladophora rupestris (Linnaeus)

Cladophora vadorum (Areschoug)

Rhizoclonium tortuosum (Dillwyn) Kützing16 $\begin{array}{lllllllll}1 & 2 & 3 & 5 & 6 & 7 & 8 & 9 & 10\end{array}$ 


\section{Stations}

Cladophora globulina (Ktitzing) Kiitzingx

Caulerpa prolifera (Forsskaal) Lamouroux

Derbesia tenuissima (Moris et De Notaris)

\section{Bryopsidales- Bryopsidaceae}

Bryopsis plumosa (hudson) C. Agardh, 1823

\section{Dasycladales-Polyphysaceae}

Acetabularia acetabulum (Linnaeus) P.C.Silva

Rhodophyceae

Acrochaetiales-Acrochaetiaceae

Audouinella codii (Crouan) Garbary

Gelidium latifolium (Grey.) Born. et Thur.

Gelidium pusillum (Stackhouse) Le Jolis

\section{Gigartinales}

Gigartina acicularis (Roth) Lamouroux

Hypnea musciformis (Wulfen) Lamouroux

Gigartina acicularis (Roth) Lamouroux

Gymnogongrus griffithsiae (Turner) Martens

Caulacanthus ustulatus (Mertens) Kiltzing

Gracilariales-Gracilariaceae

Gracilaria armata (C.Agardh) J.Agardh

Gracilaria bursa-pastoris (S .G.Gmel.) Silva 1952

Gracilaria verrucosa (Hudson) Papenfuss

Gracilaria gracilis (Stackhouse) M. Steentoft, L.M. Irvine \& W.F. Farnham,1995

\section{Cryptonemiales}

Grateloupia filicina C. Agardh

$x$

$\begin{array}{lllllll}x & & & x & & & \\ x & x & x & x & x & x \\ x & x & & & & \end{array}$

$\mathrm{x}$

$\mathrm{x}$

$\begin{array}{ll}x & x \\ x & x \\ x & x\end{array}$

X

$\begin{array}{llllll}x & x & x & x & x \\ x & & x & x & x \\ x & x & & & \\ x & & & \end{array}$

$x$

$\mathrm{x}$

$x \quad x \quad x$

$\mathrm{x} \quad \mathrm{x}$

$\begin{array}{cccccc}x & x & x & x & x & x \\ x & & x & x & x\end{array}$

\section{Rhodymeniales}




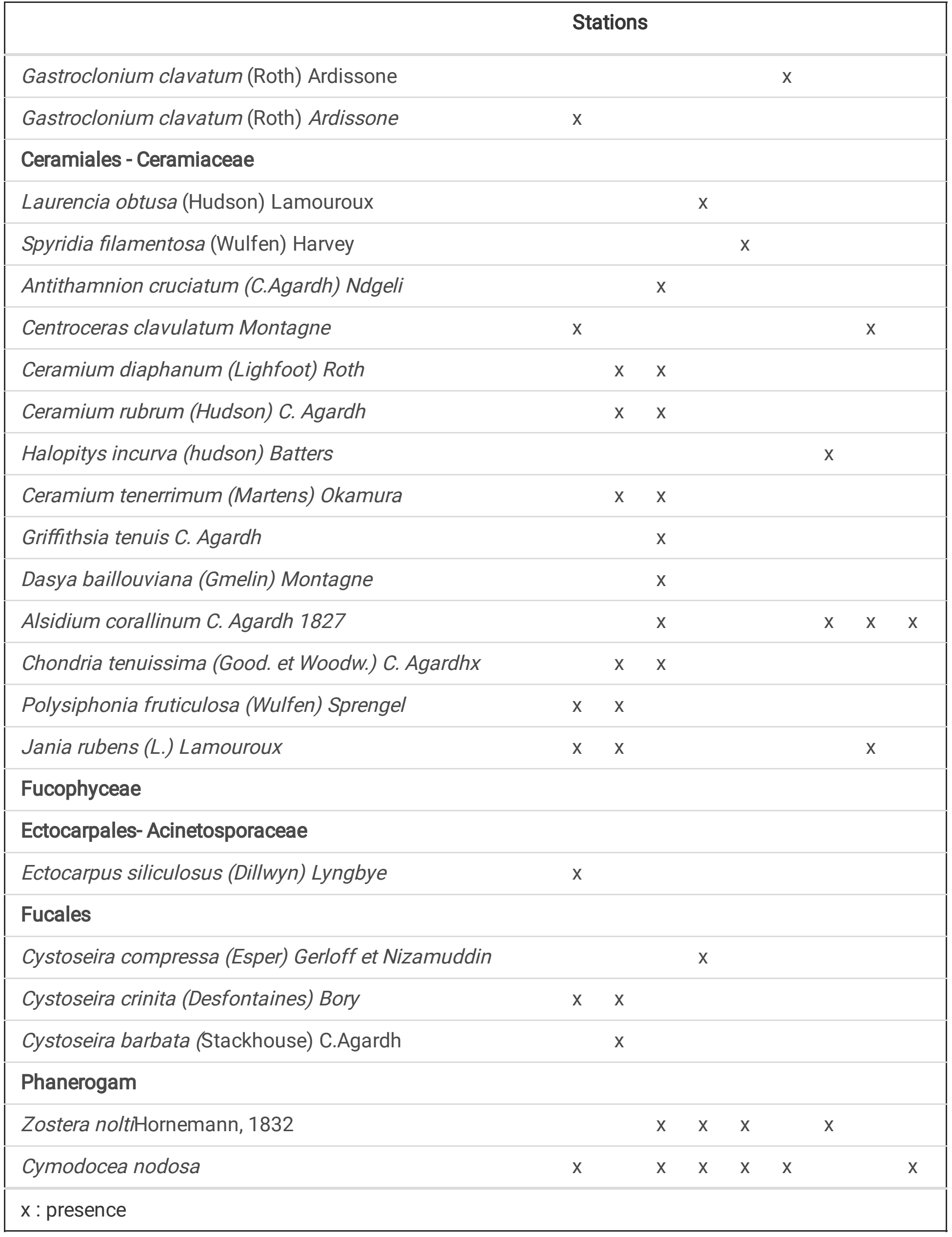


Whereas, the miximum number of species with 38 taxa was found at station 3 near the new pass. This station is close to the exchange between the lagoon and the Mediterranean Sea and the minimum with 10 taxa was at station 7 representing the south of the lagoon (Fig. 2). It should be noted that some stations are sterile to algae, notably station 4 (in the sector of the pass) and station 11 (in the center of the lagoon).

There were the spatial and temporel differences in the seaweeds, the number of species and species diversity. We noticed the dominance and diversity of rhodophyceae which are represented by the order Ceramiales (13 species) at stations 2, 3 and the order Gigartinales (10 species) at station 10, followed by the filamentous chlorophyceae: Enteromorphs and Ulves. Ulves are present in the north-east, south and south-west of the lagoon.

The algal flora is rich diversity in the north-western part (near the new pass) and decreases remarkably at the lido cord (Mohandiss area) as well as towards the continental edge (along the Bou Areg plain).

In spring, this period characterized by the beginning of the temperature increase, we noticed a high diversity of chlorophyceae, namely the ulvales (11 species) (Enteromorpha and Ulva) with maximum dominance at stations 1, 2, 6 and 8, of Chladophora (13 species) mainly the Chaetomorpha, at stations 1 and 6. Knowing that in the Kariat-Arekman station (S6), chlorophyceae are the most dominant. In autumn and winter, we have recorded a diversity and abundance of rhodophyceae which correspond to the most numerous species compared to the other groups, they are dominated by Gracilaria sp. and Sargassum, located mainly in continental areas where they are situated near the Oued Tirkâa (S10), Boukana (S2), near Oued Selouan (S8), and near the new pass (S3).

Moreover, the difference between the total number of taxa (59) and the number of taxa encountered at station 3 indicates that more than 21 species are rhodophyceae capable of withstanding strong variations in environmental conditions and better adapted to the ecological conditions of the lagoon.

\section{Discussions}

In this study, the seaweeds was composed of 59 taxa, 26 species of which were chlorophyceae, 29 species were rhodophyceae and 4 fucophyceae, which showed the qualitative importance of Marchica lagoon. In general, the most important groups were rhodophyceae in species numbers. There are many studies that were conducted in lagoons mediterranean and some of those were focused on seaweeds. In the studies carried out in the Thau lagoon (Verlaque 2001), Venice lagoon (Sfriso, et al 2020), rhodophyceae were found to be dominant compared to the other classes.

In the present work, the taxonomic composition of algal populations in the Marchica lagoon is largely influenced by the seasons, with an increase in algal population during spring and winter and a decrease during summer and autumn. While that Li et al (1984) and Marinho-Soriano et al (2006) found that the growth rate of marine plants increases during spring and summer and decreases during autumn and winter. Chlorophyceae make up the majority of the stand during the spring period, but during the summer 
period the stand experiences a decrease in chlorophyceae and an increase in rhodophyceae. These species are mainly located on the continental edge where they are situated near Oued Tirkâa (S10), which is characterized by anthropic inputs and nutrient richness at the southeast and southern end of the lagoon (Aknaf et al 2017). We noticed an abundance of Gracilaria and a proliferation of Ulve. According to phenology, the spring period shows great diversity, as vegetative growth is increased with a greater presence of reproductive organs, while the autumn and winter periods show low diversity throughout the lagoon. For the two stations ( 4 and 11) have conned of sterility, could be explained by the strong hydrodynamics related (station 4) to the increase in the strength of the currents which, consequently, leads to the removal and/or prevention of the fixation of spores and the installation of young shoots, and at station 11, could be explained by the absence of nutrients which are a limiting factor for the development of the algae (Quaratnta et al 2021).

Numerous studies have shown that the growth and development of algae is mainly related to physicochemical factors such as light, temperature, $\mathrm{pH}$ and enrichment of the medium with nutrient salts and carbonates (Quartino et al. 2005; Yakovleva et al. 2001). Indeed, the growth of most algal species shows seasonal fluctuations due to variations in these environmental factors (Silva and Santos 2003). In spring periode, the chlorophyceae are the most dominant in station 6 , this could be due to the environmental factors that interact with them, giving the best conditions for the development and growth of algae, especially water temperature $\left(23.7^{\circ} \mathrm{C}\right)$, salinity $(38.25 \mathrm{~g} / \mathrm{l})$, site oxygen $(9.83 \mathrm{mg} / \mathrm{l})$, and nutrients (Aknaf et al. 2017c). In contrast, during the summer period, there is a clear increase in temperature and a decrease in dissolved oxygen content, causing an episodic phenomenon of strong eutrophication (Aissa 1991; Dridi 1977; Dellali and Aissa 1998), caused by the nitrogen and phosphate enriched nutrients in the lagoon (El Madani 2012) which the nitrogen is the limiting factor for the algal growth (Quaranta et al. 2021). This is evidence of the increase in the degree of eutrophication recognised in previous studies (Bloundi et al. 2008), and we have also noticed that when salinity increases, algae become less abundant during the summer period. In autumn and winter haveexperienced an abundance of rhodophyceae, mainly at the stations $(2,3,8$ and 10$)$, can be explain this diversity, the higher nutritive elements concentrations (Aknaf et al 2017c). While for the fucophyceae, we noticed the dominance of Cystoseira, we cite: $C$. barbata, $C$. compressa; $C$. crinite. The species Cystoseira barbata (Fig. 3) has not been reported by Gonzalez and Conde (1991); it has been observed in abundance in the deeper areas of the lagoon and the present parts of the substrate. This species is competitive with Alsidium corallinum and Gracilaria sp.

About rhodophyceae, the order Ceramiale is associated with other species such as Hypnea musciformis and Gigartina acicularis, as well as with chlorophyceae such as Enteromorpha and with Fucophyceae (Cystoseaira). These species are mainly located in north-east of lagoon (stations 1 and 2). This great diversity of algae is related to the sandy areas and gastropod shell of the lagoon, while the muddy and sandy habitats, dominant in the lagoon (Aknfa et al. 2021), are particularly rich in chlorophyceae: Chaetomorphe sp. and Enteromorph sp., Cladophora sp. and Caulerpa prolifera. This last species is the most dominant among the chlorophyceae, it has been encountered in association with Zostera noltii and Cymodocea nodosa. They are fixed on muddy and sandy-muddy substrates, the same result was noted 
by Najih et al (2016), but rhodophyceae, we have noticed that a few species are fixed on bivalves mainly at stations 3 and 8 .

Specific richnessof seaweeds in Marchica lagoon were compared with others lagoons (Mar menor, Ghar El Mellah, Venis lagoon and Thau lagoon) in Mediterranean Sea (Table 2). The comparison revealed that the difference observed concerns mainly the algae, since the number of phanerogams varies between 1 and 4, while for the seeweads; the number of species oscillates between 15 and 323. For the lagoon Marchica the algal poverty comparing with the lagoon of Venice (Italy) and Thau (France) can be explained by the quasi absence of solid substrates (rocks/ gravel) except on the continental border of the lagoon.

Table 2

Comparison of the Floristic richness (NT) of Marchica lagoon with others lagoons in the Mediterranean for Rhodophyceae (Rh), Chlorophyceae (Ch), Fucophyceae (Fu) and Phanerogams $(\mathrm{Ph})$

\begin{tabular}{|lllllll|}
\hline Locality & Ch & Rh & Fu & Ph & NT & Refrences \\
\hline Mar menor-Spain & 27 & 29 & 19 & 4 & 79 & Perez-Ruzafa (1990) \\
Ghar El Mellah- Tunisia & 11 & 0 & 0 & 4 & 15 & Romdhane et Chakroun (1986) \\
Venise (Italy) & 84 & 179 & 59 & 1 & 323 & Sfriso et al 2019 \\
Thau-France & 42 & 99 & 55 & 1 & 179 & Verlaque, 2001 \\
Marchica lagoon-Morocco & 26 & 29 & 4 & 2 & 61 & Present study \\
\hline
\end{tabular}

The dominant species were a total of 10 species are: Ulva rigida, Ulva fasciata, Chaetomorpha area, Enteromorpha intestinalis, Enteromorpha compressa and Caulerpa prolifera about Chlorophyceae. For Rhodophyceae, Alsidium corallinium and Gracilarea gracilis and for Fucophyceae, Cystosiera compressa and Cystoseira compressa. This study indicate that temperature and nutrients played important roles in the variation of distribution of seaweeds in Marchica lagoon.

\section{Declarations}

Acknowledgements Thanks to the reviewers for their improvements to this manuscript and to the subject matter experts who contributed to the manuscript revision. We would like to thank Mr Mesfioui Albdehakim and the diver Mr Chihani Ahmed from INRH Nador-Morocco for thr logistic support and help to carry out the sampling of algae throughout the seasonal monitoring campaigns.

Funding The authors declare that they have no known competing financial interests.

Conflict of Interest The authors declare no conflict of interest.

Ethical Approval Not applicable. 
Sampling and field studies Samples were produced in collaboration with the National Institute of Fisheries Research in Nador.

Data availability The datasets generated and/or analyzed during the current study are available from the corresponding author upon reasonable request.

Author Contribution AA was responsible for the planning of the work, sampling and taxonomy, $A A, M B$ and $B O, M A, M L, M B$ and $B O$, performed the methodology and analysis, and $A A$ and $B O$ had a major contributor in writing the manuscript. All authors read and approved the final manuscript.

\section{References}

1. Aknaf A, Akodad M, Layachi M, Baghour M, Oudra B, Vasconcelos V (2022) The chemical characterization and its relationship with heavy metals contamination in surface sediment of Marchica Mediterranean Lagoon (North of Morocco). Environ Sci Pollut Res 29:4159-4169. https://doi.org/10.1007/s11356-021-15641-4

2. Aknaf A, Akodad M, Layachi M, Baghour M, Oudra B (2018) Metal contamination of sediments in the Marchica lagoon (North-East Morocco): An ecotoxicological diagnostic. SMETox J 1:123-127

3. Aknaf A, Akodad M, Layachi M, Oudra B, Baghour M (2020) Pollution biomonitoring in the Nador lagoon using algae and physico-chemical parameters. J Appl Environ Sci 3:3-4

4. Aknaf A, Akodad M, Layachi M, Mesfioui A, Andich K, Baghour M (2017) Granulometric analysis and environment of deposits of surface sediments of the Marchica lagoon (North-East of Morocco). Recent advances in environmental science from the euro-Mediterranean and surrounding regions, vols i and II, Book Series: Adv sci technol Innov pp. 1677-1678. https://doi.org/10.1007/978-3-31970548-4_487

5. Aknaf A, Akodad M, Layachi M, El Madani F, Jaddar A, Mesfioui A, Baghour M (2017b) Study of the spatial and temporal variation of physical-chemical parameters characterizing the quality of surface waters of the lagoon Marchica - NorthEast Morocco. J Mater Environ Sci 8:3216-3226

6. Aknaf A, Akodad M, Moumen A, Chekroun KB, Elhamouti C, Bailal A, Baghour M (2015) Impact of the new pass on the eutrophication of the lagoon Marchica: Study of the two sites Bou Areg and Mohandis. J Mater Environ Sci 6:2939-2943

7. Allmendinger A, Spavieri J, Kaiser M, Casey R, Hingley-Wilson S, Lalvani A, Tasdemir D (2010) Antiprotozoal, antimycobacterial and cytotoxic potential of twenty-three British and Irish red algae. Phytother Res 24:1099-1103. https://doi.org/10.1002/ptr.3094

8. Bloundi MK, Faure P, Duplay J (2008) Organic contamination identification in sediments from a Mediterranean coastal ecosystem: The case of the Nador Lagoon (Eastern Morocco). C R -. Geosci 340:840-849. https://doi.org/10.1016/j.crte.2008.08.007

9. Cabioc'h J, Floc'h J-Y, Le Toquin A, Boudouresque CF, Meinesz A, Verlaque M (2006) Guide des algues des mers d'Europe (Manche et Atlantique) (Méditerranée) 
10. Cardozo KH, Vessecchi R, Carvalho VM, Pinto E, Gates PJ, Colepicolo P, Chouba L, Ajjabi-Chebil L, Herry $S$ et al (2010) Etude saisonnière de la contamination métallique des macroalgues de la lagune nord de. Tunis Bull Inst Natn Scien 37:123-131

11. Couteau C, et Coiffard L (2016) Seaweed application in cosmetics. In: Seaweed in health and disease prevention. Universitv of Names, Nantes, France. Academic Press. pp 423-441. https://doi.org/10.1016/B978-0-12-802772-1.00014-2

12. Custódio L, Nafis A, El Khalloufi F, Aknaf A, Oudra B, Marraiki N, Hassani L (2021) In vitro antimicrobial and synergistic effect of essential oil from the red macroalgae Centroceras clavulatum (C. Agardh) Montagne with conventional antibiotics. Asian Pac J Trop Biomed 11(9):414. https://doi 10.4103/2221-1691.321129

13. Dellali M, Aissa P (1998) État de pollution de la lagune de Bizerte. Bull Inst Nat Sci Tech Mer 26:5660

14. Didderen I, Destain J, Thonart $P$ (2008) Le bioéthanol de seconde génération: la production d'éthanol à partir de biomasse lignocellulosique. Presses agronomiques de Gembloux. p 108

15. Dridi S (1977) Recherches écologiques sur les milieux lagunaires du nord de la Tunisie. Thèse de spécialité, Faculté des sciences, Tunis

16. El Asri O, Ramdani M, Latrach L, Haloui B, Afilal ME (2017a) Comparison of energy recovery after anaerobic digestion of three Marchica lagoon algae (Caulerpa prolifera, Colpomenia sinuosa, Gracilaria bursa-pastoris). Sustain Mater Technol 11:47-52. https://doi.org/10.1016/j.susmat.2016.12.002

17. El Asri O, Ramdani M, Latrach L, Haloui B, Mohamed R, elamin Afilal M (2017b) Energetic valorization of Nador lagoon algae and proposal to use it as a means of elimination of the eutrophication in this lagoon. Ecol Eng 103:236-243. https://doi.org/10.1016/j.ecoleng.2017.04.016

18. Ely R, Supriya T, Naik CG (2004) Antimicrobial activity of marine organisms collected off the coast of South East India. J Exp Mar Biol Ecol 309(1):121-127

19. Febles Cl, Arias A, Gil-Rodriguez MC, Hardisson A, Sierra Lopez A (1995) In vitro study of antimicrobial activity in algae (Chlorophyta, Phaeophyta and Rhodophyta) collected from the coast of Tenerife. Anuario del Instituto de Estudios Canarios 34:181-192

20. Figueira MM, Volesky B, Ciminelli VST (1997) Assessment of interference in biosorption of a heavy metal Biotechnol Bioeng 54. 344-350. https://doi.org/10.1002/(SICI)1097-0290(19970520)54:4. 4

21. Fourest E, Volesky B (1997) Alginate properties and heavy metal biosorption by marine algae. Appl Biochem Biotechnol 67(3):215-226. https://doi.org/10.1007/BF02788799

22. Gonzalez J, Conde F (1991) Estudio florisco, Fenologico, autoecologico y fitogeografico del macrofitobentos de la mar chica (Sebcha Buareg de Nador, mediterraneo marroqui). Acta Bot Malacit 16(1):63-80

23. Guiry MD, Guiry GM (2012) AlgaeBase. Worldwide electronic publication. National University of Ireland, Galway. http://www.algaebase.com 
24. Hankamer Lehr F, Rupprecht J, Mussgnug JH, Posten C, Kruse $O$ (2007) Photosynthetic biomass and $\mathrm{H}_{2}$ production by green algae: from bioengineering to bioreactor scale-up. Physiol Plant 131(1):1021. https://doi.org/10.1111/j.1399-3054.2007.00924.x

25. Holan ZR, Volesky B (1994) Biosorption of lead and nickel by biomass of marine algae. Biotechnol Bioeng 43(11):1001-1009. https://doi.org/10.1002/bit.260431102

26. Iltis A (1980) Les algues. Lévêque C. (ed.). Flore et faune aquatiques del'Afrique sahélo-soudanienne. 1:9-61

27. Inci T, Bilge H, Çadircl D, Atakan S (2006) Antimicrobial Activity of the Extracts of Marine Algae from Coast of Urla (Izmir, Turkey). Turk J Biol 30:171-175

28. Jaulneau V, Lafitte C, Jacquet C, Fournier S, Salamagne S, Briand X, Esquerre-Tugaye M-T, Dumas B (2010) Ulvan, a Sulfated Polysaccharide from Green Algae, Activates Plant Immunity through the Jasmonic Acid Signaling Pathway. J biotechnol biomed 1-11. https://doi.org/10.1155/2010/525291

29. Kaimoussi A, Mouzdahir A, Saih A (2004) Variations saisonnières des teneurs en métaux (Cd, $\mathrm{Cu}, \mathrm{Fe}$, $\mathrm{Mn}$ et $\mathrm{Zn}$ ) chez l'algue Ulva lactuca prélevée au niveau du littoral de la ville d'El Jadida (Maroc). C R Biol 327(4):361-369. https://doi.org/10.1016/j.crvi.2004.01.007

30. Kasting JF, Siefert JL (2002) Life and the evolution of Earth's atmosphere. Science 296:1066-1068

31. khelil-Radji F, Belhouari MY, Chemlal-Kherraz D, Matallah-Boutiba A, Boutiba Z (2017) Antimicrobial activity of aqueous and ethanol extracts of two marine algae collected from Algerian west coast. Int J Biosci 10:217-222. DOI http://dx.doi.org/10.12692/ijb/10.3.217-222

32. Kuyucak N, Volesky B (1988) Biosorbents for recovery of metals from industrial solutions. Biotechnol Lett 10(2):137-142. https://doi.org/10.1007/BF01024641

33. Lauret M, Jocelyne O, Ifremer, Sète (2011) Laboratoire Environnement/Ressources LER/LR.Université de Montpellier. p 148

34. Li R, Chong R, Meng Z (1984) A preliminary study of raft cultivation of Gracilaria verrucosa and Gracilaria sjoestedtii. Hydrobiologia 252-254. https://doi.org/10.1007/978-94-009-6560-7_47

35. Li Y, Qian ZJ, Ryu B, Lee SH, Kim MM, Kim SK (2009) Chemical components and its antioxidant properties in vito: An edible marine brown alga, Ecklonia cava. Bioorg et Med Chem Carbohyd res 296:237-247. https://doi.org/10.1016/j.bmc.2009.01.031

36. Lima-Filho JVM, Carvalho AF, Freitas SM, Melo VM (2002) Antibacterial activity of extracts of six macroalgae from the northeastern Brazilian coast. Braz J Microbiol 33(4):311-314

37. Marinho-Soriano E, Fonseca PC, Carneiro MAA, Moreira WSC (2006) Seasonal variation in the chemical composition of two tropical seaweeds. Bioresour Technol 97:2402-2406. https://doi.org/10.1016/j.biortech.2005.10.014

38. Matoir M, Belabed A, Najih M, Kada O, Rezzoume N (2015) Surrounding influence on the Ecological state of the lagoon of Marchica. J Mater Environ Sci 6(5):1260-1265 
39. Mišurcová L, Škrovánková S, Samek D, Ambrožová J, Machů L (2012) Health benefits of algal polysaccharides in human nutrition. Adv Food Nutr Res 66:75-145. https://doi.org/10.1016/B978-012-394597-6.00003-3

40. Nahas R, Abatis D, Anagnostopoulou MA, Kefalas P, Vagias C, Roussi V (2007) Radicla scavenging activity of Aegean Dea marine algae. Food Chem 102:577-581. https://doi.org/10.1016/j.foodchem.2006.05.036

41. Oumaskour KHADIJA, Boujaber NABILA, Etahiri SAMIRA, Assobhei OMAR (2013) Anti-inflammatory and antimicrobial activities of twenty-tree marine red algae from the coast of Sidi Bouzid (El JadidaMorocco). Int j pharm and Pharm Sc 5:145-149

42. Pereira L, Cotas J (2020) Introductory Chapter: Alginates-A General Overview. Alginates-Recent Uses of This Natural Polymer

43. Pereira L, Neto JM (eds) (2014) (Eds.) Marine Algae: Biodiversity, Taxonomy, Environmental Assessment, and Biotechnology. CRC Press, Boca Raton, FL, USA

44. Quaranta G, Bloundi MK, Duplay J, Clauer N (2021) The eutrophication process of Nador's lagoon (Morocco) evaluated by the Life Cycle Impact Assessment method. Arab J Geosci 14(5):1-8. https://doi.org/10.1007/s12517-021-06685-4

45. Quartino ML, Zaixso HE, de Boraso AL (2005) Biological and environmental characterization of marine macroalgal assemblages in Potter Cove, South Shetland Islands, Antarctica. Bot Mar 48:187-197. https://doi.org/10.1515/bot.2005.029

46. Perez-Ruzafa I (1990) Fenologia de las algas del Mar Menor (Murcia, SE de Espaňa). Bot Complutensis 16:21-36

47. Romdhane MS, Chakroun FK (1986) Les peuplements benthiques de la lagune de Ghar el Melh Bull Inst Natn Sc Tech Océanogr Pêche Salambô. Tunisie 13:95-108

48. Verlaque M (2001) Checklist of the macroalgae of Thau Lagoon (Hérault, France), a hot spot of marine species introduction in Europe. Oceanol Acta 24(1):29-49

49. Rahmouni R, Bouden S, Oueslati W, Sbei A, Chaabani F (2016) Les Algues Indicatrices De L'eutrophisation Et De La Contamination De La Lagune De Korba (Cap Bon Tunisie). Eur Sci J 12:17. URL:http://dx.doi.org/10.19044/esj.2016.v12n17p149

50. Ruiz F, Abad M, Galan E, Gonzalez I, Aguila E, Hamouni N, Pulidi I, Cantano M (2006) The present environmental scenario of the Nador Lagoon (Morocco). Environ Res 102:215-229. https://doi.org/10.1016/j.envres.2006.03.001

51. Seckbach J (2010) Introduction to globally changing environment. In: Israel A, Einav R, Seckbach J (eds) Seaweeds and their role in globally changing environments. Springer, London, pp 15-19

52. Sfriso A, Buosi A, Tomio Y, Wolf MA, Juhmani AS, Sfriso AA (2019) Macroalgae in the lagoon of Venice: long-term changes, alien taxa and environmental impact. 7th European Phycological Congress, 25-30 August, Zagabria, p 95

53. Sfriso A, Buosi A, Wolf MA, Sfriso AA (2020) Invasion of alien macroalgae in the Venice Lagoon, a pest or a resource? Aquat Invasions 15(2). https://doi.org/10.3391/ai.2020.15.2.03 
54. Silva J, Santos R (2003) Comparative ecophysiology of Gelidium sesquipedale (Rhodophyta). Erect fronds and prostat system. Proceeding of the 17th international seaweed symposium Cape town, A. R. O. Chapman, R. J. Anderson, V. Vreeland and T. R. Davison (eds), Oxford University press. pp 417424

55. Spavieri J, Allmendinger A, Kaiser M, Itoe MA, Blunden G, Mota MM, Tasdemir D (2013) Assessment of dual life stage antiplasmodial activity of British seaweeds.Marine Drugs11:4019-4034. https://doi.org/10.3390/md11104019

56. Trono GC (1973) Seaweeds: one of the important marine natural resources of the Philippines in the Gregorio T. Velasquez Lecture Series. Challenge to the biologists in the 70's: the escalation of food production.NRCP Publication,28-4l

57. Vasarri M, Ramazzotti M, Tiribilli B, Barletta E, Pretti C, Mulinacci N, Degl'Innocenti D (2020) The in vitro anti-amyloidogenic activity of the mediterranean red seaweed Halopithys incurva. Pharmaceuticals 13:1-15. https://doi.org/10.3390/ph13080185

58. Verlaque M (2001) Checklist of the macroalgae of Thau Lagoon (Hérault, France), a hot spot of marine species introduction in Europe. Oceanol Acta 24(1):29-49

59. Viessman W, Hammer MJ, Perez EM, Chadik PA (2009) Water supply and pollution control. Pearson Prentice Hall, New Jersey

60. Yakovleva IM, Yermak I, Titlyanov M, Barabanova EA, Glazunov AO, Skriptsova VP AV (2001) Changes in growth rate, anatomy and polysaccharide content of a sterile form of Tichocarpus crinitus (Gmel.) Rupr. (Rhodophyta, Tichocarpaceae) grown under differing photon irradiances in the Sea of Japan, Russia. Bot Mar 44(5):493-500. https://doi.org/10.1515/BOT.2001.055

61. Zbakh H, Salhi G, Moussa H, Riadi H (2014) Cytotoxic and antioxidant activities of the red seaweed Halopithys incurve. Int j adv pharm biol Chim 3:1043-1047

62. Zerrouqi Z, Sbaa M, Chafi A, Aqil H (2013) Contribution à l'étude de la qualité des eaux de la lagune de Nador: Impact de l'anthropisation. Bulletin de l'Institut Scientifique, Rabat, Section Sciences de la Vie 35: 51-59

\section{Figures}




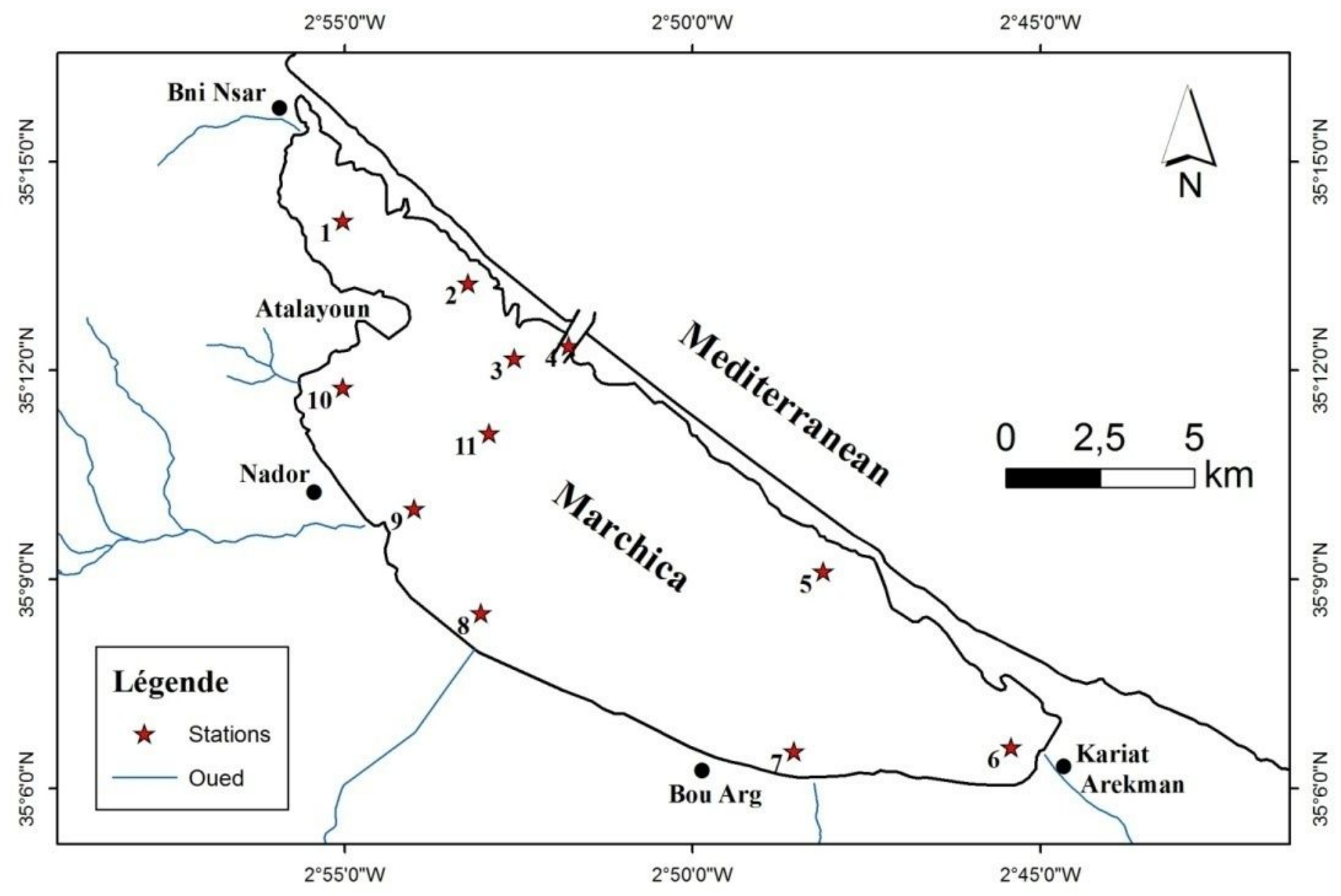

Figure 1

Network of Seaweeds sampling sites 


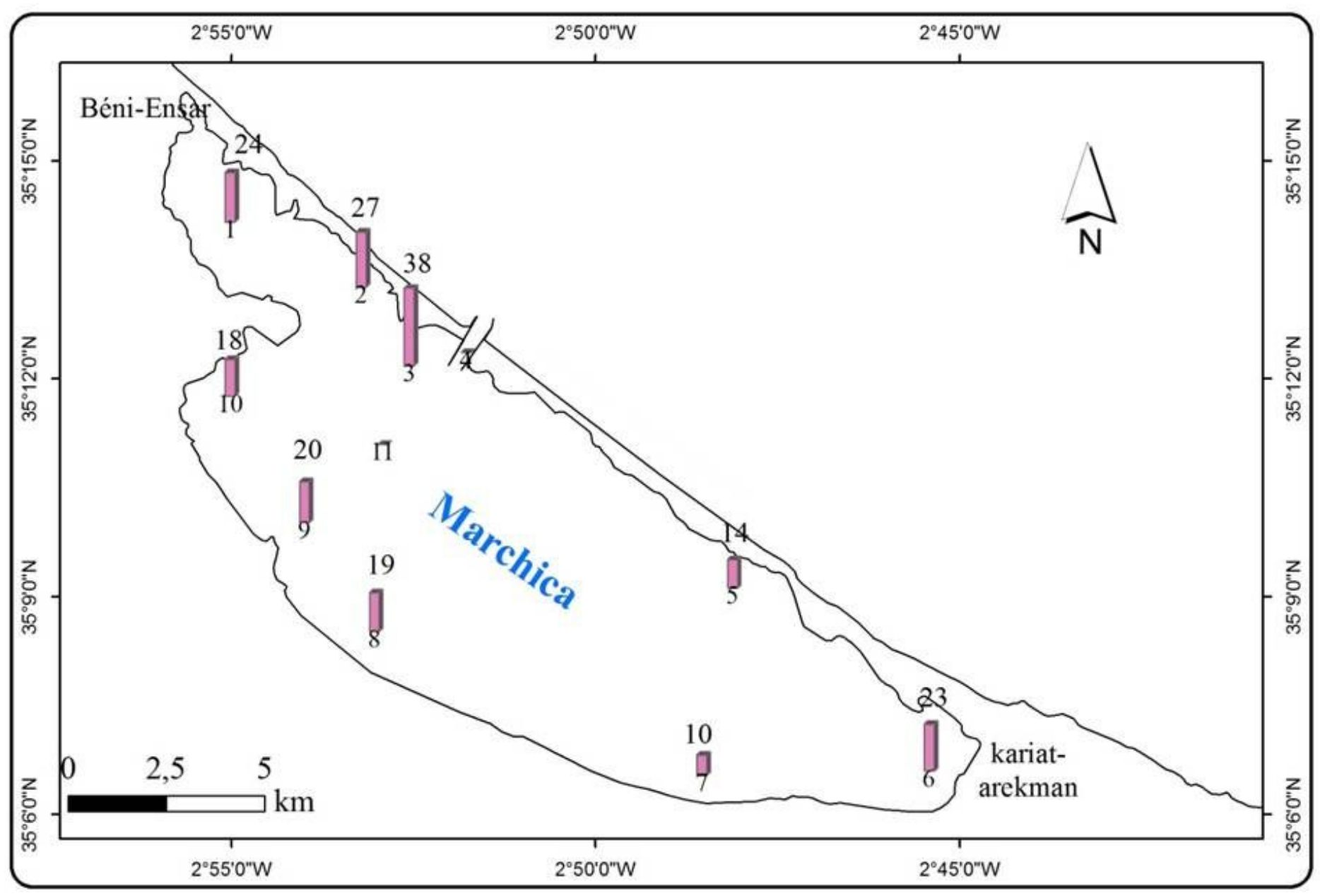

Figure 2

Spatial distribution of algae in the Marchica lagoon

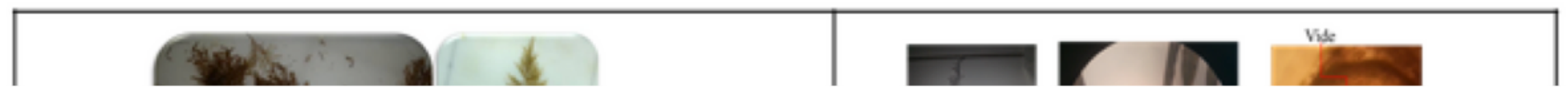

Figure 3

Brown algae (Phaeophyta) 